Article history: Submitted 2 September 2021; Accepted 9 September 2021; Available online 26 October 2021.

\title{
Politik Hukum Pidana Pengelolaan Eks Dana Program Nasional Pemberdayaan Masyarakat Mandiri Perdesaan (PNPM-MPd)
}

\author{
Aris Tri Wibowo, Abdul Madjid dan Rachmi Sulistyarini \\ aristw70@gmail.com \\ Universitas Brawijaya, Malang
}

\begin{abstract}
Keywords: $\quad$ Abstract
Political Law; The management of the former PNPM-MPd funds does not yet have a legal umbrella, Former Fund both laws, and regulations in other forms. Based on this, the authors see that there are of The National legal problems, namely a legal vacuum (vacuum of Recht) regarding the management of Program for former PNPM-MPd funds so that they have the potential to cause state financial losses Rural Community (corruption). This paper includes normative juridical research with a statue approach Empowerment; and a conceptual approach. The results showed that the management of former PNPMCriminal Acts of MPd funds was not explicitly regulated in statutory regulations. The potential for the Corruption. occurrence of criminal acts of corruption to be exposed, as evidenced by the existence of criminal acts of corruption regarding the abuse of authority, resulting in losses to state finances. So that it takes legal politics to formulate the management of former PNPMMPd funds so as not to harm state finances (the occurrence of criminal acts of corruption).
\end{abstract}

\section{Kata Kunci: $\quad$ Abstrak}

Politik Hukum; Pengelolaan eks dana PNPM-MPd belum memiliki payung hukum baik Eks Dana undang-undang maupun peraturan dalam bentuk yang lainnya. Berdasarkan Program Nasional hal tersebut, penulis melihat terdapat permasalahan hukum yaitu kekosongan Pemberdayaan hukum (vacuum of recht) mengenai pengaturan pengelolaan eks dana PNPMMasyarakat MPd sehingga berpotensi untuk menimbulkan kerugian keuangan negara Perdesaan; Tindak (tindak pidana korupsi). Makalah ini termasuk penelitian yuridis normatif Pidana Korupsi. dengan pendekatan peraturan perundang-undangan (statue approach), dan pendekatan konseptual (conseptual approach). Hasil penelitian menunjukkan bahwa pengelolaan eks dana PNPM-MPd tidak diatur secara eksplisit di dalam peraturan perundang-undangan. Potensi terjadinya tindak pidana korupsi menjadi terbuka, terbukti dengan adanya tindak pidana korupsi mengenai penyalahgunaan kewenangan sehingga menimbulkan kerugian keuangan negara. Sehingga diperlukan politik hukum untuk melakukan formulasi pengelolaan eks dana PNPM-MPd agar tidak merugikan keuangan negara (terjadinya tindak pidana korupsi).

Copyright () 2021 Aris Tri Wibowo, Abdul Madjid dan Rachmi Sulistyarini. (c) (i)() () Published in Media Iuris. Published by Universitas Airlangga, Magister Ilmu Hukum. (cc)

\section{Pendahuluan}

Dalam mengimplentasikan negara kesejahteraan secara berkelanjutan, negara memiliki tugas dan tanggungjawab untuk memberikan perhatian dan keberpihakan yang adil antara mendorong pertumbuhan ekonomi dengan 
keadilan distribusi pendapatan sehingga tercapai pemerataan kesejahteraan. ${ }^{1}$ Berbagai strategi, kebijakan maupun program yang di desain tetap memberikan eksklusifitas pada kelompok masyarakat dan rumah tangga yang masih berada pada tingkat kesejahteraan dibawah termasuk didalamnya adalah yang terkait dengan pembangunan desa maupun instrumen lembaga ekonomi, sosial, budaya. ${ }^{2}$

Salah satu prioritas pembangunan pemerintahan Kabinet Kerja RI ialah "membangun Indonesia dari pinggiran dengan memperkuat daerah dan desa". Orientasi pembangunan tersebut juga menjadi latar belakang terbitnya Undang-Undang Nomer 6 tahun 2014 tentang Desa yang menjadi instrumen utama pemerintah dalam melaksanakan agenda-agenda pembangunan perdesaan. Lewat pelaksanaan Undang-undang tersebut, Kementerian Desa, Pembangunan Daerah Tertinggal dan Transmigrasi (Kemendes PDTT) kini mengemban amanah sebagai pelaksana tugas dan fungsi bidang pembangunan desa dan pemberdayaan masyarakat. ${ }^{3}$ Termasuk di dalam tugas Kemendes PDT adalah melanjutkan agenda-agenda pembangunan yang dilaksanakan di era pemerintahan sebelumnya, salah satunya Program Nasional Pemberdayaan Masyarakat - Mandiri Perdesaan (PNPM-MPd) yang telah diakhiri programnya seiring dengan terbitnya UU Desa.

Program Nasional Pemberdayaan Masyarakat - Mandiri Perdesaan (PNPMMPd) merupakan salah satu upaya pemerintah untuk mendorong penurunan angka kemiskinan dan pengangguran. PNPM Mandiri difokuskan pada program penanggulangan kemiskinan yangberbasis partisipasi dan pemberdayaan masyarakat ${ }^{4}$ PNPM Mandiri merupakan integrasi dan perluasan programprogram penanggulangan kemiskinan yang berbasis masyarakat yang sudah jalan. Program yang sudah alan tersebut adalah P2KP dan PPK kedua program

\footnotetext{
${ }^{1}$ Khuzdaifah Dimyati Absori Elviandri, ‘Quo Vadis Kesejahteraan: Meneguhkan Ideologi Walfare State Negara Hukum Kesejahteraan Indonesia' (2019) 31 Mimbar Hukum.[252].

${ }^{2}$ Suradi, ‘Pertumbuhan Ekonomi Dan Kesejahteraan Sosial' (2012) 17 Jurnal Informasi.[144].

${ }^{3}$ D.S Priyarsono, 'Membangun Dari Pinggir: Tinjauan Dari Perspektif Ilmu Ekonomi Regional' (2017) 1 Journal of Regional and Rural Development Planing.[ 42-52].

${ }^{4}$ PNPM, 'Program Nasional Pemberdayaan Masyarakat Mandiri' (PNPM) <https://www. pnpm-mandiri.org/Sejarah.html> accessed 10 September 2021.
} 
tersebut telah berjalan sebelum PNPM Mandiri terbentuk. PNPM Mandiri sendiri dikukuhkan secara resmi oleh Presiden RI pada 30 April 2007 di Kota Palu, Sulawesi Tengah. ${ }^{5}$

PNPM Mandiri adalah program nasional dalam wujud kerangka kebijakan sebagai dasar dan acuan pelaksanaan program-program penanggulangan kemiskinan berbasis pemberdayaan masyarakat. PNPM Mandiri dilaksanakan melalui harmonisasi dan pengembangan sistem serta mekanisme dan prosedur program, penyediaan pendampingan, dan pendanaan stimulan untuk mendorong prakarsa dan inovasi masyarakat dalam upaya penanggulangan kemiskinan yang berkelanjutan. ${ }^{6}$ Pemberdayaan masyarakat adalah upaya untuk menciptakan/ meningkatkan kapasitas masyarakat, baik secara individu maupun berkelompok, dalam memecahkan berbagai persoalan terkait upaya peningkatan kualitas hidup, kemandirian, dan kesejahteraannya. Pemberdayaan masyarakat memerlukan keterlibatan yang lebih besar dari perangkat pemerintah daerah serta berbagai pihak untuk memberikan kesempatan dan menjamin keberlanjutan berbagai hasil yang dicapai Program Nasional Pemberdayaan Masyarakat (PNPM) Mandiri yang dicanangkan oleh Pemerintah Indonesia ada 3 jenis antara lain yaitu PNPM Mandiri Perdesaan, PNPM Mandiri Perkotaan, dan PNPM mandiri Wilayah Khusus dan Desa Tertinggal. ${ }^{7}$

PNPM-MPd adalah program untuk mempercepat penanggulangan kemiskinan secara terpadu dan berkelanjutan. Pendekatan PNPM Mandiri Perdesaan merupakan pengembangan dari Program Pengembangan Kecamatan (PPK), yang selama ini dinilai berhasil. Beberapa keberhasilan PPK adalah berupa penyediaan lapangan kerja dan pendapatan bagi kelompok rakyat miskin,

${ }^{5}$ Raisa Betsida Hutabarat, 'Pelaksanaan Program Nasional Pemberdayaan Masyarakat Mandiri Perdesaan (PNPPMd) Di Kecamatan Siak Hulu Kabupaten Kampar' (2016) 3 JOM FISIP. [1-10].

${ }^{6}$ Tim Penyusun Pedoman Umum PNPM-Mandiri, 'Pedoman Umum Program Pemberdayaan Masyarakat Mandiri' (2007) <http://jdih.bpk.go.id/Wp-Content/Uploads/2012/02/PedomanPNPM-Mandiri_UMUM.Pdf> accessed 4 June 2021.

7 Direktorat Jenderal Pemberdayaan Masyarakat dan Des, 'Petunjuk Teknis Operasional Program Nasional Pemberdayaan Masyarakat Mandiri Perdesaan' <http://lkmupksinergis.com/ Wp-Content/Uploads/2016/02/01_PTO-PNPM-MPd.Pdf> accessed 4 June 2021.[5]. 
Aris Tri, dkk: Politik Hukum Pidana...

efisiensi dan efektivitas kegiatan, serta berhasil menumbuhkan kebersamaan dan partisipasi masyarakat. ${ }^{8}$

Visi PNPM Mandiri Perdesaan adalah tercapainya kesejahteraan dan kemandirian masyarakat miskin perdesaan. Kesejahteraan berarti terpenuhinya kebutuhan dasar masyarakat. Kemandirian berarti mampu mengorganisir diri untuk memobilisasi sumber daya yang ada di Iingkungannya, mampu mengakses surnber daya di luar lingkungannya, serta mengelola sumber daya tersebut untuk mengatasi masalah kemiskinan. Misi PNPM Mandiri Perdesaan adalah: (1) peningkatan kapasitas masyarakat dan kelembagaannya; (2) pelembagaandan pengintegrasian pembangunan partisipatif; (3) pengefektifan fungsi dan pecan pemerintahan lokal, (4) peningkatan kualitas dan kuantitas prasarana sarana sosial dasar dan ekonomi masyarakat; (5) pengembangan jaringan kemitraan dalam pembangunan. ${ }^{9}$

Tujuan UmumPNPMMandiriPerdesaanadalahmeningkatnyakesejahteraan dan kesempatan kerja masyarakat miskin di perdesaan dengan mendorong kemandirian dalam pengambilan keputusan dan pengelolaan pembangunan yang berkelanjutan. Tujuan khususnya meliputi: ${ }^{10}$

1. Meningkatkan partisipasi seluruh masyarakat, khususnya masyarakat miskin dan atau kelompok perempuan dan masyarakat adat dalam pengambilan keputusan perencanaan, pelaksanaan, pemantauan dan pelestarian pembangunan;

2. Menyatupadukan sistem pembangunan partisipatif model PNPM MPd dan program sejenis ke dalam sistem pembangunan regular;

3. Melembagakan pengelolaan pembangunan partisipatif dengan mendayagunakan sumber daya manusia dan sumber daya alam lokal dengan mempertimbangkan kelestariannya;

4. Mengembangkan kapasitas kelembagaan masyarakat, pemerintahan khususnya pemerintahan desa dalam fasilitasi pengelolaan pembangunan partisipatif yang berwawasan lingkungan;

5. Menyediakan prasarana sarana sosial dasar dan ekonomi yang diprioritaskan oleh masyarakat;

6. Melembagakan pengelolaan dana bergulir;

\footnotetext{
${ }^{8}$ Riyanto Siaga Basu Murbeng, 'Mochamad Saleh Soeaidy, 'Pelaksanaan Program Nasional Pemberdayaan Masyarakat Mandiri Perdesaan (PNPM MP) (Studi Pada Desa Bendungan Kecamatan Gondang Kabupaten Tulungagung)' (2017) 1 Jurnal Administrasi Publik.[1257].

${ }^{9}$ Direktorat Jenderal Pemberdayaan Masyarakat dan Desa, Loc.Cit.

${ }^{10}$ ibid.[6].
} 
7. Mendorong terbentuk dan berkembangnya kerjasama antar desa;

8. Mengembangkan kerja sama antar pemangku kepentingan dalam upaya penanggulangan kemiskinan perdesaan dan perbaikan lingkungan hidup.

Pengembangan jaringan kemitraan dalam pembangunan dalam rangka mencapai visi dan misi PNPM Mandiri Pedesaan, strategi yang dikembangkan PNPM Mandiri Pedesaan yaitu menjadikan rumah tangga miskin (RTM) sebagai kelompok sasaran, menguatkan system pembangunan partisipatif, serta mengembangkan kelembagaan kerjasama antar desa. Berdasarkan visi, misi, dan strategi yang dikembangkan, maka PNPM Mandiri Pedesaan lebih menekankan pentingnya pemberdayaan sebagai pendekatan yang dipilih. Melalui PNPM Mandiri Pedesaan diharapkan masyarakat dapat menuntaskan tahapan pemberdayaan yaitu tercapainya kemandirian dan berkelanjutan, setelah tahapan pembelajaran dilakukan melalui Progran Pengembangan Kecamatan. ${ }^{11}$

Program pemberdayaan masyarakat ini dapat dikatakan sebagai program pemberdayaan masyarakat terbesar di tanah air. Pelaksanaan PNPM Mandiri Perdesaan berada di bawah binaan Direktorat Jenderal Pemberdayaan Masyarakat dan Desa (PMD), Kementerian Dalam Negeri. Program ini didukung dengan pembiayaan yang berasal dari alokasi Program ini didukung dengan pembiayaan yang bersumber dari alokasi Anggaran Pendapatan dan Belanja Negara $(\mathrm{APBN})$, alokasi Anggaran Pendapatan dan Belanja Daerah (APBD), partisipasi dari Corporante Social Responsibility (CSR), dana hibah, swadaya masyarakat dan pinjaman dari sejumlah lembaga. Program ini memusatkan kegiatan bagi masyarakat Indonesia paling miskin di wilayah perdesaan, menyediakan fasilitas pemberdayaan masyarakat/kelembagaan lokal, pendampingan, pelatihan, serta dana Bantuan Langsung untuk Masyarakat (BLM) kepada masyarakat secara langsung. Besaran dana BLM yang dialokasikan sebesar Rp 750 juta sampai Rp 3 miliar per kecamatan, tergantung jumlah penduduk. PNPM Mandiri Perdesaan mengadopsi sepenuhnya mekanisme dan prosedur Program Pengembangan

${ }^{11}$ Ubaidullah M. Aidhil Sahlan, ‘Pengaruh Pelaksanaan Program Nasional Pemberdayaan Masyarakat (PNPM) Mandiri Perdesaan Dalam Mengurangi Kemiskinan’ (2019) 4 Jurnal Ilmiah Mahasiswa FISIP Unsyiah.[1-15]. 
Kecamatan (PPK) yang telah dilaksanakan sejak 1998. Dalam PNPM Mandiri Perdesaan, seluruh anggota masyarakat diajak terlibat dalam setiap tahapan kegiatan secara partisipatif, mulai dari proses perencanaan, pengambilan keputusan dalam penggunaan dan pengelolaan dana sesuai kebutuhan paling prioritas di desanya, sampai pada pelaksanaan kegiatan dan pelestariannya. ${ }^{12}$

Berakhirnya PNPM-MPd secara programatik bertepatan pula dengan berakhirnya masa kekuasaan pemerintah pengagas PNPM-MPd. Tindak lanjut berakhirnya PNPM Mpd tahun 2014 ditandai dengan telah diserahterimakan pembinaannya dari Kemendagri ke Kemendes PDTT melalui Berita Acara Serah Terima PNPM MPD Nomor 100/1694/SJ dan Nomor 01/BA:M-DPDTT/IV/2015 tertanggal 7 April 2015 berupa aset sarana dan prasarana serta dana bergulir masyarakat. Namun, hingga kini pembahasan khusus mengenai keberlanjutan dana bergulir masyarakat masih terus berlangsung akibat belum memiliki payung hukum yang kuat tentang bagaimana mengelola dan keberlanjutannya.

Permasalahan hukum (legal issue) dalam pengelolaan dana eks PNPM-MPd ialah kekosongan hukum (recht vacuum) mengenai dasar hukum atau aturan hukum yang mengatur mengenai program tersebut. Tidak adanya dasar hukum mengenai peralihan PNPM-MPd menjadikan permasalahan penyalahgunaan dana eks-PNPM-MPd ini oleh pengurus (tindak pidana korupsi), dan hal tersebut akan menjadi kendala bagi penyidik dalam menerapkan pasal UU Tindak Pidana Korupsi khusunya dalam memenuhi unsur "perbuatan melawan hukum"

Berdasarkan permasalahan di atas, penulis tertarik untuk menyusun dalam makalah dengan judul "Politik Hukum Pidana Pengelolaan Eks Dana Program Nasional Pemberdayaan Mandiri Perdesaan (PNPM-MPd) (Perspektif Pencegahan Tindak Pidana Korupsi)". Jenis penelitian ini adalah yuridis normatif. Penelitian normatif dalam penelitian ini digunakan untuk menemukan aturan hukum, prinsip-prinsip hukum, guna menjawab isu hukum terkait Politik hukum pidana Pengelolaan Eks Program Nasional Pemberdayaan Masyarakat Mandiri

12 ibid. 
Perdesaan (PNPM-MPd) sebagai sarana pencegahan tindak pidana korupsi. Penulis menggunakan dua pendekatan dalam penelitian ini yaitu statue approach dan conceptual approach. Adapun bahan hukum terdiri dari Bahan Hukum Primer, Bahan Hukum Sekunder dan Bahan Hukum Tersier.

\section{Metode Penelitian}

Penelitian ini merupakan penelitian hukum normatif. Penelitian hukum normatif merupakan penelitian yang difokuskan untuk mengkaji kaidah atau norma pada hukum positi. ${ }^{13}$ Penelitian ini merupakan penelitian hukum normative. Penelitian hukum normatif merupakan penelitian yang difokuskan untuk mengkaji kaidah atau norma pada hukum positif. Pendekatan dalam penelitian ini ialah pendekatan peraturan perundang - undangan (statue approach) dan pendekatan konseptual (conseptual apporoach). Metode interprestasi yang digunakan dalam penelitian ini yaitu : interprestasi gramatikal ; interprestasi sistematik ; interprestasi futuristik.

\section{Dasar Hukum Program Nasional Pemberdayaan Masyarakat Mandiri Perdesaan (PNPM-MPd) di Indonesia}

Kemiskinan di Indonesia dipandang akan tetap menjadi masalah yang perlu untuk diselesaikan secara nasional. Kemiskinan merupakan masalah yang ditandai oleh berbagai hal antara lain rendahnya kualitas hidup penduduk, terbatasnya kecukupan dan mutu pangan, terbatasnya dan rendahnya mutu layanan kesehatan, gizi anak, dan rendahnya mutu layanan pendidikan. ${ }^{14}$

Berbagai cara telah dilakukan pemerintah untuk menurunkan tingkat kemiskinan di Indonesia. Salah satu upaya pemerintah untuk menanggulangi kemiskinan antara lain Program Nasional Pemberdayaan Masyarakat Mandiri (PNPM Mandiri). PNPM Mandiri sendiri telah dilaksanakan sejak tahun 2007,

${ }^{13}$ Johny Ibrahim, Teori Dan Metodologi Penelitian Hukum Normatif (Banyumedia 2011).[295].

${ }_{14}$ Muhaimin, 'Analisis Hukum Terhadap Efektivitas Pelaksanaan Kebijakan Pemerintah Dalam Pengentasan Kemiskinan Dan Model Penyelesaiannya’ (2012) 12 Jurnal Dinamika Hukum. [16-20]. 
sebagai wujud dasar dan acuan pelaksanaan program-program kemiskinan berbasis pemberdayaan masyarakat.

PNPM Mandiri memiliki beberapa program yang terdiri dari PNPM Mandiri Perdesaan, PNPM Mandiri Perkotaan, serta PNPM Mandiri wilayah khusus dan desa tertinggal. PNPM Mandiri Perdesaan (PNPM MPd) adalah program untuk mempercepat penanggulangan kemiskinan secara terpadu dan berkelanjutan. Pendekatan PNPM MPd merupakan pengembangan dari Program Pengembangan Kecamatan (PPK), yang selama ini dinilai berhasil. ${ }^{15}$

Dalam sub bab ini akan diuraikan mengenai dasar hukum PNPM MPd sejak awal dilaksanakannya PNPM MPd yaitu tahun 2007. Secara filosofis, dasar pelaksanaan PNPM MPd ialah konstitusi dalam hal ini Undang-Undang Dasar Negara Republik Indonesia Tahun 1945 (untuk selanjutnya disingkat UUD 1945). Namun, selain konstitusi terdapat beberapa peraturan perundang-undangan yang mendasari PNPM MPd. Untuk menguraikan dasar hukum PNPM MPd, dibawah ini akan terbagi dalam beberapa bagian antara lain:

a) Undang-Undang Nomor 17 Tahun 2007 tentang Rencana Pembangunan Jangka Panjang Nasional Tahun 2005-2025

Secara eksplisit Undang-Undang Nomor 17 Tahun 2007 tentang Rencana Pembangunan Jangka Panjang Nasional Tahun 2005 - 20025 (untuk selanjutnya disebut UU RPJP) tidak mengatur mengenai PNPM MPd. Melainkan dalam UU RPJP merupakan payung hukum perencanaan pembangunan jangka panjang, yang meliputi RJP Nasional, RPJP Daerah, Rencana Pembangunan Jangka Menengah (RPJMN) Nasional, dan RPJM Daerah.

RPJP Nasional merupakan penjabaran dari tujuan dibentuknya Pemerintahan Negara Indonesia yang tercantum dalam Pembukaan UUD 1945, yaitu untuk melindungi segenap bangsa dan seluruh tumpah daerah Indonesia, memajukan kesejahteraan umum, mencerdaskan kehidupan bangsa,

15 Departemen Dalam Negeri Direktorat Jenderal Pemberdayaan Masyarakat dan Desa, Petunjuk Teknis Operasional (PTO) Program Nasional Pemberdayaan Masyarakat Mandiri (PNPM) Mandiri Perdesaan (2008).[2]. 
dan ikut melaksanakan ketertiban dunia yang berdasarkan kemerdekaan, perdamaian abadi, dan keadilan sosial dalam bentuk rumusan visi, misi dan arah Pembangunan Nasional. ${ }^{16}$

Dengan visi pembangunan nasional tahun 2005-2025 “Indonesia Yang Mandiri, Maju, Adil dan Makmur", terdapat 8 (delapan) misi pembangunan nasional. Salah satunya ialah berkaitan dengan penanggulangan kemiskinan, antara lain terdapat dalam misi angka ke-5 yaitu mewujudkan pemerataan pembangunan dan berkeadilan. Salah satunya dengan menanggulangi kemiskinan dan pengangguran secara drastis. ${ }^{17}$

UU RPJP juga menjadi payung hukum dibuatnya RPJM Nasional, yang merupakan dokumen perencanaan pembangunan nasional untuk periode 5 (lima) tahunan, yaitu RPJM Nasional I Tahun 2005-2009, RPJM Nasional II Tahun 2010-2014, RPJM Nasional III Tahun 2015-2019, dan RPJM Nasional IV Tahun 2020-2024.

b) Peraturan Presiden Nomor 7 Tahun 2005 tentang Rencana Pembangunan Jangka Menengah Nasional Tahun 2004-2009

Dalam Peraturan Presiden Nomor 7 Tahun 2005 tentang Rencana Pembangunan Jangka Menengah Nasional Tahun 2004-2009 (untuk selanjutnya disebut Perpres RPJMN I), tidak mengatur secara eksplisit mengenai PNPM MPd. Namun, "roh" PNPM MPd terdapat dalam RPJMN I. Diantaranya terdapat dalam Agenda Meningkatkan Kesejahteraan Masyarakat. ${ }^{18}$

Untuk mencapai peningkatan kesejahteraan masyarakat tersebut, disusun prioritas dan arah kebijakan pembangunan salah satunya ialah Penanggulangan Kemiskinan, dengan kebijakan yang diarahkan untuk menghormati, melindungi dan memenuhi hak-hak dasar masyarakat miskin yang meliputi hak atas pangan, kesehatan, pendidikan, pekerjaan, perumahan,

\footnotetext{
${ }^{16}$ Pasal 3 UU Nomor 17 Tahun 2007 tentang Rencana Pembangunan Jangka Panjang Nasional Tahun 2005-2025.

17 Lampiran UU Nomor 17 Tahun 2007 tentang Rencana Pembangunan Jangka Panjang Nasional Tahun 2005-2025.

${ }^{18}$ Lampiran Perpres No 7 Tahun 2005 tentang Rencana Pembangunan Jangka Menengah Nasional Tahun 2005-2009.
} 
air bersih, tanah, lingkungan hidup dan sumber daya alam, rasa aman, serta hak untuk berpartisipasi dalam perumusan kebijakan publik. ${ }^{19}$

Kemiskinan merupakan salah satu fokus masalah nasional yang ingin diselesaikan oleh Pemerintah pada saat itu. Terbukti dengan bagian ke-IV RPJMN I tersebut sasaran pertama agenda meningkatkan kesejahteraan rakyat ialah dengan pengurangan kemiskinan dan pengangguran.

c) Peraturan Presiden Nomor 54 Tahun 2005 tentang Tim Koordinasi

\section{Penanggulangan Kemiskinan}

Dalam Peraturan Presiden Nomor 54 Tahun 2005 tentang Tim Koordinasi Penanggulangan Kemiskinan (untuk selanjutnya disebut Perpres TKPK) juga tidak menyebutkan secara eksplisit mengenai PNPM MPd, melainkan Perpres TKPK membentuk Tim Koordinasi Penanggulangan Kemiskinan yang merupakan forum lintas sektor sebagai wadah koordinasi penanggulangan kemiskinan, yang berada dibawah dan bertanggungjawab kepada Presiden, yang dipimpin oleh Menteri Negara Koordinasi Bidang Kesejahteraan Rakyat. ${ }^{20}$

TKPK memiliki tugas melakukan langkah-langkah konkrit untuk mempercepat pengurangan jumlah penduduk miskin di seluruh wilayah Negara Kesatuan Republik Indonesia melalui koordinasi dan sinkronisasi penyusunan dan pelaksanaan penajaman kebijakan penanggulangan kemiskinan. ${ }^{21}$ Dalam Perpres TKPK tersebut juga mengatur fungsi TKPK, organisasi TKPK, sekretariat TKPK, kelompok kerja TKPK, tata kerja TKPK, dan pembiayaan TKPK.

d) Keputusan Menteri Koordinator Kesejahteraan Rakyat selaku Ketua Tim Koordinasi Penanggulangan Kemiskinan No. 25/KEP/MENKO/KESRA/ VII/2007 tentang Pedoman Umum Program Pemberdayaan Masyarakat Mandiri (PNPM Mandiri)

Berdasarkan Perpres TKPK, TKPK memiliki tugas untuk melakukan

\footnotetext{
${ }^{19}$ ibid.

${ }^{20}$ Pasal 1 Perpres No 54 Tahun 2005 tentang Tim Koordinasi Penanggulangan Kemiskinan.

${ }^{21}$ Pasal 2 Perpres No 54 Tahun 2005 tentang Tim Koordinasi Penanggulangan Kemiskinan.
} 
langkah-langkah konkrit untuk mempercepat pengurangan jumlah penduduk miskin di seluruh wilayah NKRI melalui penyusunan dan pelaksanaan penajaman kebijakan penanggulangan kemiskinan. Berdasarkan tugas tersebut pula, ketua TKPK mengeluarkan Keputusan Menteri Koordinator Bidang Kesejahteraan Rakyat No.25/KEP/MENKO/KESRA/VII/2007 tentang Pedoman Umum Program Pemberdayaan Masyarakat Mandiri (untuk selanjutnya disebut PEDUM PNPM Mandiri).

Secara eksplisit dalam PEDUM PNPM Mandiri tersebut mengatur mengenai latar belakang dibentuknya PNPM Mandiri, pengertian PNPM Mandiri, tujuan PNPM Mandiri, strategi PNPM Mandiri sampai dengan pendanaan PNPM Mandiri.

PNPM Mandiriadalah program nasional dalam wujud kerangka kebijakan sebagai dasar dan acuan pelaksanaan program-program penanggulangan kemiskinan berbasis pemberdayaan masyarakat. PNPM mandiri dilaksanakan melalui harmonisasi dan pengembangan sistem serta mekanisme dan prosedur program, penyediaan, pendampingan, dan pendanaan stimulan untuk mendorong prakarsa dan inovasi masyarakat dalam upaya penanggulangan kemiskinan yang berkelanjutan. ${ }^{22}$

e) Surat Menteri Dalam Negeri Nomor 414.2/2634/PMD tanggal 29 Desember 2008 perihal Petunjuk Pelaksanaan PNPM Mandiri Perdesaan PPK T.A. 2008

Dalam Surat Menteri Dalam Negeri Nomor 414.2/2634/PMD tanggal 29 Desember 2008 perihal Petunjuk Pelaksanaan PNPM Mandiri Perdesaan PPK T.A. 2008 (untuk selanjutnya disingkat PTO PNPM MPd Tahun 2008) berisi secara lengkap dan eksplisit mengenai pelaksanaan PNPM MPd. Mulai dari latar belakang sampai dengan pengelolaan pengaduan masalah.

PTO PNPM MPd Tahun 2008 merupakan penjabaran dari PEDUM PNPM Mandiri yang dikeluarkan oleh ketua TKPK, yang lebih spesifik mengatur mengenai satu program PNPM Mandiri yaitu PNPM MPd. PNPM

${ }^{22}$ Tim Penyusun Pedoman Umum PNPM-Mandiri (n 6). Op.Cit.[5]. 
MPd secara umum bertujuan meningkatkan kesejahteraan dan kesempatan kerja masyarakat miskin di perdesaan dengan mendorong kemandirian dalam pengambilan keputusan dan pengelolaan pembangunan. ${ }^{23}$ Dalam PNPM MPd memiliki kelompok sasaran rumah tangga miskin di perdesaan, kelembagaan masyarakat di perdesaan, dan kelembagaan pemerintahan lokal.

f) Surat Menteri Dalam Negeri Nomor 414.2/3101/PMD tanggal 24 April 2014 perihal Petunjuk Teknis Operasional PNPM Mandiri Perdesaan T.A. 2014

PTO PNPM MPd tahun 2008 menjadi dasar dilaksanakannya PNPM MPd diseluruh Indonesia setidaknya sampai tahun 2014. Karena, pada tahun 2014 terdapat revisi terhadap PTO PNPM MPd Tahun 2008 melalui Surat Menteri Dalam Negeri Nomor 414.2/3101/PMD tanggal 24 April 2014 perihal Petunjuk Teknis Operasional PNPM Mandiri Perdesaan T.A. 2014 (untuk selanjutnya disingkat PTO PNPM MPd Tahun 2014).

Adapun terdapat beberapa perbaikan dalam PTO PNPM MPd Tahun 2014, yakni pada tujuan secara umum dan khusus, keluaran program, prinsip dasar, kelompok sasaran, dan sebagainya. Beberapa perbaikan tersebut berdasarkan evaluasi terhadap PNPM MPd yang sudah berjalan dalam 6 (enam) tahun terakhir.

Tindak Pidana Korupsi Dalam pengelolaan Eks Dana Program Nasional Pemberdayaan Masyarakat Mandiri Perdesaan (PNPM-MPd) di Indonesia

Melihat dari runtutan dasar hukum yang diuraikan di atas, memang tidak ada peraturan perundang-undangan baik dalam bentuk undang-undang maupun peraturan presiden yang secara eksplisit mengatur mengenai PNPM MPd. Namun, PNPM MPd merupakan kebijakan dan program yang nyata untuk merealisasikan tujuan dan program pemerintah dalam RPJP Nasional dan RPJM Nasional yaitu untuk meningkatkan kesejahteraan rakyat Indonesia dengan cara menanggulangi Cit.[2].

${ }^{23}$ Departemen Dalam Negeri Direktorat Jenderal Pemberdayaan Masyarakat dan Desa, Op. 
kemiskinan dan pengangguran secara derastis. ${ }^{24}$ Sehingga, walaupun PNPM MPd tidak memiliki dasar hukum berdasarkan amanat undang-undang secara langsung, namun tujuan dari PNPM MPd sejalan dengan undang-undang yaitu UU RPJP, Perpres RPJMN I, Perpres TPPK, sampai pada petunjuk teknis operasional.

Ide dasar mewujudkan kesejahteraan rakyat melalui PNPM-MPd harus dijaga dan dilaksanakan. Untuk mengurangi penyalahgunaan pelanggaran dan menggerus konsep kesejahteraan rakyat yang diinginkan dari PNPM-MPd melalui program pengentasan kemiskinan dan pengangguran yang ada di masyarakat tentu harus diwujudkan sejak ide tersebut masih di bawah pikiran. Untuk itu diperlukan formulasi payung hukum berupa peraturan perundang-undangan baik dalam bentuk undang-undang maupun peraturan pelaksana lainnya agar PNPM-MPd dapat berjalan dengan baik. ${ }^{25}$

Temuan di lapangan tentu menjadi salah satu faktor yang kuat untuk dilakukan reformasi dan evaluasi penyelenggaraan PNPM-MPd. Baik di sektor regulasi maupun di sektor penyelenggaraan lapangan. Sehingga penyusunan regulasi demi mewujudkan kesejahteraan rakyat menjadi hal utama dan pokok dalam pelaksanaan PNPM-MPd selanjutnya.

Potensi terjadinya tindak pidana korupsi menjadi terbuka ketika lemahnya substansi (regulasi) yang mengatur mengenai pengelolaan eks dana PNPM-MPd. Hal ini dibuktikan dengan adanya penyalahgunaan kewenangan yang terjadi di Kabupaten Madiun. Perkara tersebut dilakukan oleh Yayuk Puji Lestari dengan mengakibatkan kerugian keuangan negara dengan total Rp. 781.800.000,- (tujuh ratus delapan puluh satu juta delapan ratus ribu rupiah).

Yayuk Puji Lestari melakukan rangkaian sidang dari Pengadilan Tingkat Pertama (Pengadilan Tindak Pidana Korupsi pada Pengadilan Negeri Surabaya) hingga pada tingkat Kasasi di Mahkamah Agung. Terdakwa divonis terbukti

${ }^{24}$ Sandy Ari Wijaya, ‘Dasar Hukum Lembaga Keuangan Simpan Pinjam Eks Program PNPM Mandiri Pedesaan (Studi Kasus Di Kantor BKAD Kecamatan Montong Gading' (2017) 5 Journal Ilmiah Rinjani Universitas Gunung Rinjani.[41-45].

25 I.G.W Murjana Yasa Nyoman, et. al 'Efektivitas Dan Dampak Program Nasional Pemberdayaan Masyarakat-Mandiri Perdesaan (PNP-MPd) Di Kecamatan Denpasar Utara' (2018) 7 E-Jurnal Ekonomi dan Bisnis Universitas Udayana.[367]. 
secara sah dan meyakinkan bersalah melakukan tindak pidana "korupsi secara berlanjut" dan menjatuhkan pidana penjara selama 4 (empat) tahun dengan denda sebesar Rp. 200.000.000,- (dua ratus juta rupiah). ${ }^{26}$

Yayuk Puji Lestari dikenakan 2 ayat (1) juncto Pasal 18 ayat (1) huruf b UU No 31 Tahun 1999 sebagaimana diubah dengan UU No 20 Tahun 200. Modus yang dilakukan ialah melakukan manipulasi berkiatan dengan proporsal Sistem Pinjam Perempuan (SPP) dan Usaha Ekonomi Produktif (UEP) dengan memberikan data tidak sesuai dengan kebenaran (fiktif).

Politik Hukum Pidana pengelolaan eks dana Program Nasional Pemberdayaan Masyarakat Mandiri Perdesaan (PNPM-MPd) Berdasarkan Perspektif

\section{Pencegahan Tindak Pidana Korupsi}

Diskursus mengenai politik hukum dalam ilmu hukum sering kali dimulai dengan memberikan kerangka epistimologis mengenai hubungan politik dan hukum sebagai bentuk pembedaan dengan teori positivisme hukum. Politik menurut Otto Von Bismarck yaitu suatu pertaruhan kemungkinan untuk merebut kemungkinan yang lebih besar, dimana dalam hal itu terdapat nilai yang diperjuangkan dan tujuan yang hendak diraih. Maka politik tidak hanya menyangkut suatu cara mencapai tujuan melalui rasionalitas instrumental atau Zweckratioanalitaet yang merupakan ajaran Max Weber. ${ }^{27}$ Politik lebih dari pragmatisme simplitis yang mengandung sifat eksistensial dalam wujudnya karena melibatkan rasionalitas nilai-nilai.

Menurut Satjipto Rahardjo Politik Hukum adalah sebuah aktivitas untuk menempuh sebuah tujuan hukum tertentu yaitu dimana para pembentuk hukum melakukan sebuah aktivitas yaitu perencanaan mengenai hukum apa yang akan dibentuk dalam sebuah periode tertentu. ${ }^{28}$ Hukum bukan suatu lembaga yang otonom, melainkan berada pada kedudukan yang saling terkait dengan

${ }^{26}$ Putusan Mahkamah Agung Nomor 578 K/Pid.Sus/2019.

${ }^{27}$ Merdi Hjiji, 'Relasi Hukum Dan Politik Dalam Sistem Hukum Indonesia' (2013) 2 Jurnal Rechtvinding.[361].

${ }^{28}$ Satjipto Rahardjo, Ilmu Hukum (Citra Aditya Bhakti 2012).[398]. 
sektor kehidupan lain dalam masyarakat dimana hukum juga terpengaruh dari masyarakat baik secara sosiologis maupun antropologis. ${ }^{29}$

Oleh sebab itu maka hukum harus melakukan penyesuaian terhadap tujuan yang ingin dicapai oleh masyarakatnya, ${ }^{30}$ yaitu politik hukum itu sendiri, yang akan menimbulkan dinamika dalam masyarakat karena diarahkan kepada iure constituendo atau hukum yang seharusnya berlaku bukan hukum yang ada. Maka politik hukum akan melakukan perencanaan-perencanaan terhadap hukum yang kemudian akan diaplikasikan kepada masyarakat yang menemui dinamika penerimaan maupun penolakan. ${ }^{31}$

Melihat dari runtutan dasar hukum yang diuraikan diatas, memang tidak ada peraturan perundang-undangan baik dalam bentuk undang-undang maupun peraturan presiden yang secara eksplisit mengatur mengenai PNPM MPd. Namun, PNPM MPd merupakan kebijakan dan program yang nyata untuk merealisasikan tujuan dan program pemerintah dalam RPJP Nasional dan RPJM Nasional yaitu untuk meningkatkan kesejahteraan rakyat Indonesia dengan cara menanggulangi kemiskinan dan pengangguran secara drastis. Sehingga, walaupun PNPM MPd tidak memiliki dasar hukum berdasarkan amanat undang-undang secara langsung, namun tujuan dari PNPM MPd sejalan dengan undang-undang yaitu UU RPJP, Perpres RPJMN I, Perpres TPPK, sampai pada petunjuk teknis operasional.

Politik hukum PNPM MPd dapat terlihat yaitu untuk mewujudkan kesejahteraan rakyat Indonesia. Walaupun dalam uraian di atas tidak terdapat payung hukum yang jelas dalam penyelenggaraan PNPM MPd. Namun, kebijakan yang dilakukan pemerintah dalam hal ini penyelenggaraan PNPM MPd ialah untuk mewujudkan kesejahteraan rakyat Indonesia.

Secara konstitusional pengertian negara kesejahteraan (welfare state) ditemukan dalam Undang-Undang Dasar Negara Republik Indonesia tahun

\footnotetext{
${ }^{29}$ Nazaruddin lathif, ‘Teori Hukum Sebagai Sarana/Alat Untuk Memperbaharui Atau Merekayasa Masyarakat’ (2017) 03 Pakuan Law Review.[73-74].

${ }^{30}$ Yance Arizona, 'Negara Hukum Bernurani', Senggigi: 1st International Indonesian Law Society (2010).[24].

${ }^{31}$ Satjipto Rahardjo, Hukum Dan Perilaku (Kompas Media Nusantara 2009).[110].
} 
Aris Tri, dkk: Politik Hukum Pidana...

1945 (selanjutnya disebut UUD NRI 1945). Pasal 1 UUD NRI 1945 memberikan landasan bagi konsep politik hukum (peraturan Perundang-undangan) nasional di Indonesia yang hendak diimplementasikan. Pasal 1 UUD NRI 1945 itu dirumuskan sebagai berikut:

1) Negara Indonesia adalah Negara Kesatuan yang berbentuk republik;

2) Kedaulatan berada di tangan rakyat dan dilaksanakan menurut UndangUndang Dasar;

3) Negara Indonesia adalah negara hukum.

Berdasarkan rumusan Pasal 1 UUD NRI 1945 itu, maka konsep politik hukum (peraturan Perundang-undangan) nasional kita paling tidak dilandasi oleh 3 (tiga) prinsip yang fundamental seperti prinsip negara hukum (welfare state), prinsip negara kesatuan (unitary state) dengan bentuk pemerintah republic, dan prinsip demokrasi (democracy). ${ }^{32}$

Prinsip negara hukum yang dianut dalam konsep politik hukum (peraturan Perundang-undangan) nasional kita adalah prinsip welfare state. Prinsip ini dapat ditemukan dalam Pembukaan UUD NRI 1945 alenia keempat.

“Kemudian daripada itu untuk membentuk suatu Pemerintahan Negara Indonesia yang melindungi segenap bangsa Indonesia dan seluruh tumpah darah Indonesia dan untuk memajukan kesejahteraan umum, mencerdaskan kehidupan bangsa, dan ikut melaksanakan ketertiban dunia yang berdasarkan kemerdekaan Kebangsaan Indonesia itu".

Prinsip welfare state dalam Pembukaan UUD NRI 1945 itu mengisyaratkan agar dalam pembentukan politik perundang-undangan nasional berorientasi pada tujuan untuk:

1) Melindungi segenap bangsa Indonesia dan seluruh tumpah darah Indonesia;

2) Memajukan kesejahteraan umum;

3) Mencerdaskan kehidupan bangsa; dan

4) Ikut melaksanakan ketertiban dunia yang berdasarkan kemerdekaan, perdamaian abadi dan keadilan sosial.

${ }^{32}$ Imam Subechi, 'Mewujudkan Negara Hukum Indonesia' (2012) 1 Jurnal Hukum dan Peradilan.[340]. 
Dalam Kepustakaan asing istilah politik hukum pidana ini sering dikenal dengan berbagai istilah, antara lain penal policy, criminal law policy atau strafrechtspolitiek. ${ }^{33}$ Mengkaji politik hukum pidana akan terkait dengan politik hukum. Politik hukum terdiri atas rangkaian kata politik dan hukum. Menurut Sudarto, istilah politik dipakai dalam berbagai arti antara lain: ${ }^{34}$

1) Perkataan politiek dalam bahasa Belanda, berarti sesuatu yang berhubungan dengan negara;

2) Berarti membicarakan masalah kenegaraan atau berhubungan dengan negara.

Dengan demikian, kebijakan hukum pidana dapat diartikan dengan cara bertindak atau kebijakan dari negara (pemerintah) untuk menggunakan hukum pidana dalam mencapai tujuan tertentu, terutama dalam menanggulangi kejahatan. Memang perlu diakui bahwa banyak cara maupun usaha yang dapat dilakukan oleh setiap negara (pemerintah) dalam menanggulangi kejahatan. Salah satu upaya untuk dapat menanggulangi kejahatan, diantaranya melalui suatu kebijakan hukum pidana atau politik hukum pidana. ${ }^{35}$

Sudarto menyatakan bahwa melaksanakan politik hukum pidana berarti mengadakan pemilihan untuk mencapai hasil perundang-undangan pidana yang paling baik dalam arti memenuhi syarat keadilan dan daya guna. Politik hukum pidana berarti usaha mewujudkan peraturan perundang-undangan pidana yang sesuai dengan keadaan dan situasi pada suatu waktu dan untuk masa-masa yang akan datang. Kata sesuai dalam pengertian tersebut mengandung makna baik dalam arti memenuhi syarat keadilan dan daya guna. ${ }^{36}$

Politik hukum penyelenggaraan PNPM-MPd menjadikan hukum sebagai alat untuk mencapai tujuan yang mulia yaitu pengentasan kemiskinan di masyarakat. Dengan berakhirnya PNPM-MPd, sehingga saat ini terjadi

\footnotetext{
${ }^{33}$ Aloysius Wisnubroto, Kebijakan Hukum Pidana Dalam Penanggulangan Penyalahgunaan Komputer (Universitas Atmajaya 1999).[10].

${ }^{34}$ Teguh Prasetyo dan Abdul Halim Barkatullah, Politik Hukum Pidana: Kajian Kebijakan Kriminalisasi Dan Dekriminilisasi (Pustaka Pelajar 2015).[11].

${ }^{35}$ Aloysius Wisnubroto, Op.Cit.[10].

${ }^{36}$ Barda Nawawi Arief, Bunga Rampai Kebijakan Hukum Pidana (Citra Aditya Bhakti 1996).[24].
} 
kekosongan hukum di setiap daerah dalam hal pengelolaan eks dana PNPMMPd. Sehingga, untuk mencegah terjadinya tindak pidana korupsi atau menyebabkan kerugian keuangan negara akibat pengelolaan eks dana PNPMMPd, maka diperlukan politik hukum pidana untuk memberikan pengaturan dalam peraturan perundang-undangan. Baik dalam bentuk undang-undang, atau dengan peraturan daerah sesuai dengan potensi terjadinya penyalahgunaan kewenangan yang mengakibatkan kerugian keuangan negara (tindak pidana korupsi). Seperti yang dijelaskan di pembahasan sebelumnya yaitu Kasus yang terjadi di Madiun yang dilakukan oleh Yayuk Puji Lestari dengan mengakibatkan kerugian keuangan negara dengan total Rp. 781.800.000,- (tujuh ratus delapan puluh satu juta delapan ratus ribu rupiah).

Yayuk Puji Lestari melakukan rangkaian sidang dari Pengadilan Tingkat Pertama (Pengadilan Tindak Pidana Korupsi pada Pengadilan Negeri Surabaya) hingga pada tingkat Kasasi di Mahkamah Agung. Terdakwa divonis terbukti secara sah dan meyakinkan bersalah melakukan tindak pidana "korupsi secara berlanjut" dan menjatuhkan pidana penjara selama 4 (empat) tahun dengan denda sebesar Rp. 200.000.000,- (dua ratus juta rupiah). ${ }^{37}$

Yayuk Puji Lestari dikenakan 2 ayat (1) juncto Pasal 18 ayat (1) huruf b UU No 31 Tahun 1999 sebagaimana diubah dengan UU No 20 Tahun 200. Modus yang dilakukan ialah melakukan manipulasi berkiatan dengan proporsal Sistem Pinjam Perempuan (SPP) dan Usaha Ekonomi Produktif (UEP) dengan memberikan data tidak sesuai dengan kebenaran (fiktif).

Tindak pidana korupsi di Indonesia telah bersifat sistemik karena merasuk pada seluruh aspek kehidupan masyarakat dan menggerogoti setiap bangunan kekuasaan di negeri ini hingga ke daerah. ${ }^{38}$ Korupsi di daerah mempunyai kecenderungan meningkat tajam, seiring dengan diberlakukannya UU Pemerintahan Daerah. Pemerintah telah berupaya untuk

\footnotetext{
${ }^{37}$ Putusan Mahkamah Agung Nomor 578 K/Pid.Sus/2019.

${ }^{38}$ Wicipto Setiadi, 'Sanski Administratif Sebagai Salah Satu Instrument Penegakan Hukum Dalam Peraturan Perundang-Undangan' 6 Jurnal Legislasi Indonesia.[249].
} 
memberantasnya, dengan mengubah paradigma upaya pencegahan sebagai pondasi pemberantasan korupsi. ${ }^{39}$

Pencegahan tindak pidana korupsi juga menjadi tanggung jawab dari Pemerintah Daerah sebagai local state government yang mendapatkan pelimpahan wewenang dari Pemerintah Pusat dengan diberlakukannya otonomi daerah dan sistem desentralisasi. Pencegahan korupsi diarahkan untuk menciptakan good governance melalui reformasi birokrasi, termasuk di lingkungan Pemerintah Daerah. ${ }^{40}$ Selanjutnya, dikatakan bahwa reformasi birokrasi di Pemerintahan Daerah dilaksanakan berdasarkan principle of good governance dan denah pencegahan tindak pidana korupsi, namun belum seluruh Pemerintah Daerah menerapkannya. Center point dari reformasi birokrasi oleh Pemerintah Daerah terdiri atas sektor pelayanan publik, keuangan, administrasi, dan penegakan hukum, yang antara lain dipengaruhi oleh faktor kepemimpinan dan keteladanan dari pemimpin (kepala daerah), sistem perencanaan, pelayanan publik, pengelolaan keuangan daerah, dan pengawasan, secara transparan, akuntabel, efisien, dan partisipatif. ${ }^{41}$

Pemerintah Daerah diharapkan agar menciptakan good governance sebagai upaya pencegahan tindak pidana korupsi, yang antara lain berupa (1) adanya komitmen, kepemimpinan, dan keteladanan berdasar leadership and headship dari pimpinan; (2) sistem perencanaan bottom up sebagai good will dari pemerintah daerah dengan melibatkan seluruh elemen; (3) memperbaiki sistem keuangan dan asset daerah; (4) menerapkan one stop service dengan sistem pelayanan terpadu satu atap ataupun satu pintu, dan (5) mengimplementasikan e-governance dengan rasionalisasi PNS dan menempatkan birokrasi sebagai public servant.

Politik hukum pidana dalam pengelolaan eks dana PNPM-MPd mutlak diperlukan untuk menjadi garda awal pencegahan tindak pidana korupsi (langkah preventif) dalam sebuah peraturan perundang-undangan tingkat daerah (sesuai potensi kerugian).

\footnotetext{
${ }^{39}$ Budi Setyiyono, 'Memahami Korupsi Di Daerah Pasca Desentralisasi: Belajar Dari Empat Studi Kasus' (2017) 8 Politika 27.[27-30].

${ }^{40}$ Yogi Mahendra Deswantara, ‘Upaya Pemerintah Mewujudkan Pemerintahan Yang Bebas Dari Korupsi, Kolusi, Dan Nepotism' (2015) 8 DIH: Jurnal Ilmu Hukum.[86].

41 ibid.
} 


\section{Kesimpulan}

Terdapat kekosongan hukum pengelolaan eks dana PNPM-MPd di Indonesia. Untuk itu diperlukan politik hukum pidana pengelolaan eks dana PNPM-MPd sebagai langkah preventif (pencegahan) terjadinya kerugian keuangan negara yang diakibatkan tindak pidana korupsi. Politik hukum pidana tersebut salah satunya bisa dilakukan oleh Pemerintah Daerah dengan membentuk Peraturan Daerah (Perda) pengelolaan eks dana PNPM-MPd. Sehingga, pengelolaan eks dana PNPM-MPd tersebut memberikan rasa kepastian hukum, khususnya mengurangi bahkan menghilangkan potensi adanya kerugian keuangan negara akibat tindak pidana korupsi. Pada akhirnya, dengan langkah-langkah tersebut politik hukum PNPM MPd di Indonesia yaitu kesejahteraan rakyat Indonesia dengan cara menanggulangi kemiskinan dan pengangguran secara drastis dapat diwujudkan.

\section{Daftar Bacaan}

\section{Buku}

Arief BN, Bunga Rampai Kebijakan Hukum Pidana (Citra Aditya Bhakti 1996).

- - , Bunga Rampai Kebijakan Hukum Pidana (Citra Aditya Bhakti 2010).

Departemen Dalam Negeri Direktorat Jenderal Pemberdayaan Masyarakat dan Desa, Petunjuk Teknis Operasional (PTO) Program Nasional Pemberdayaan Masyarakat Mandiri (PNPM) Mandiri Perdesaan (2008).

Johny Ibrahim, Teori Dan Metodologi Penelitian Hukum Normatif(Banyumedia 2011).

Rahardjo S, Hukum Dan Perilaku (Kompas Media Nusantara 2009).

- - , Ilmu Hukum (Citra Aditya Bhakti 2012).

Teguh Prasetyo dan Abdul Halim Barkatullah, Politik Hukum Pidana: Kajian Kebijakan Kriminalisasi Dan Dekriminilisasi (Pustaka Pelajar 2015).

Wisnubroto A, Kebijakan Hukum Pidana Dalam Penanggulangan Penyalahgunaan Komputer (Universitas Atmajaya 1999).

Yance Arizona, 'Negara Hukum Bernurani', Senggigi: 1st International Indonesian 
Law Society (2010).

\section{Jurnal}

Absori Elviandri KD, 'Quo Vadis Kesejahteraan: Meneguhkan Ideologi Walfare State Negara Hukum Kesejahteraan Indonesia' (2019) 31 Mimbar Hukum.

Budi Setyiyono, 'Memahami Korupsi Di Daerah Pasca Desentralisasi: Belajar Dari Empat Studi Kasus' (2017) 8 Politika 27.

D.S Priyarsono, 'Membangun Dari Pinggir: Tinjauan Dari Perspektif Ilmu Ekonomi Regional' (2017) 1 Journal of Regional and Rural Development Planing.

I.G.W Murjana Yasa Nyoman, Kirwati NDS, ‘Efektivitas Dan Dampak Program Nasional Pemberdayaan Masyarakat-Mandiri Perdesaan (PNP-MPd) Di Kecamatan Denpasar Utara' (2018) 7 E-Jurnal Ekonomi dan Bisnis Universitas Udayana.

Imam Subechi, 'Mewujudkan Negara Hukum Indonesia' (2012) 1 Jurnal Hukum dan Peradilan 340.

Merdi Hjiji, 'Relasi Hukum Dan Politik Dalam Sistem Hukum Indonesia' (2013) 2 Jurnal Rechtvinding.

Muhaimin, 'Analisis Hukum Terhadap Efektivitas Pelaksanaan Kebijakan Pemerintah Dalam Pengentasan Kemiskinan Dan Model Penyelesaiannya' (2012) 12 Jurnal Dinamika Hukum.

Nazaruddin lathif, 'Teori Hukum Sebagai Sarana/ Alat Untuk Memperbaharui Atau Merekayasa Masyarakat' (2017) 03 Pakuan Law Review.

Priyarsono D., 'Membangun Dari Pinggir: Tinjauan Dari Perspektif Ilmu Ekonomi Regional' (2017) 17 Journal of Regional and Rural Development Planing 42.

Raisa Betsida Hutabarat, 'Pelaksanaan Program Nasional Pemberdayaan Masyarakat Mandiri Perdesaan (PNPPMd) Di Kecamatan Siak Hulu Kabupaten Kampar' (2016) 3 JOM FISIP.

Riyanto Siaga Basu Murbeng, 'Mochamad Saleh Soeaidy, "Pelaksanaan Program Nasional Pemberdayaan Masyarakat Mandiri Perdesaan (PNPM MP) (Studi Pada Desa Bendungan Kecamatan Gondang Kabupaten Tulungagung)' (2017) 1 Jurnal Administrasi Publik.

Sandy Ari Wijaya, 'Dasar Hukum Lembaga Keuangan Simpan Pinjam Eks Program PNPM Mandiri Pedesaan (Studi Kasus Di Kantor BKAD Kecamatan Montong 
Aris Tri, dkk: Politik Hukum Pidana...

Gading' (2017) 5 Journal Ilmiah Rinjani Universitas Gunung Rinjani.

Setiadi W, 'Sanski Administratif Sebagai Salah Satu Instrument Penegakan Hukum Dalam Peraturan Perundang-Undangan' 6 Jurnal Legislasi Indonesia.

Siaga Basu Murbeng, Mochamad Saleh Soeaidy R, 'Pelaksanaan Program Nasional Pemberdayaan Masyarakat Mandiri Perdesaan (PNPM MP) (Studi Pada Desa Bendungan Kecamatan Gondang Kabupaten Tulungagung' (2017) 1 Jurnal Administrasi Publik (JAP) 1257.

Suradi, 'Pertumbuhan Ekonomi Dan Kesejahteraan Sosial' (2012) 17 Jurnal Informasi.

Ubaidullah M. Aidhil Sahlan, 'Pengaruh Pelaksanaan Program Nasional Pemberdayaan Masyarakat (PNPM) Mandiri Perdesaan Dalam Mengurangi Kemiskinan' (2019) 4 Jurnal Ilmiah Mahasiswa FISIP Unsyiah.

Wijaya SA, 'Dasar Hukum Lembaga Keuangan Simpan Pinjam Eks Program PNPM Mandiri Pedesaan (Studi Kasus Di Kantor BKAD Kecamatan Montong Gading' (2017) 5 Journal Ilmiah Rinjani Universitas Gunung Rinjani.

Yogi Mahendra Deswantara, 'Upaya Pemerintah Mewujudkan Pemerintahan Yang Bebas Dari Korupsi, Kolusi, Dan Nepotism' (2015) 8 DIH: Jurnal Ilmu Hukum.

\section{Laman}

Direktorat Jenderal Pemberdayaan Masyarakat dan Des, 'Petunjuk Teknis Operasional Program Nasional Pemberdayaan Masyarakat Mandiri Perdesaan' <http://lkmupksinergis.com/Wp-Content/ Uploads/2016/02/01_PTO-PNPM-MPd.Pdf> accessed 4 June 2021.

PNPM,'Program Nasional Pemberdayaan Masyarakat Mandiri' (PNPM) < https:/ / www.pnpm-mandiri.org/Sejarah.html> accessed 10 September 2021.

Tim Penyusun Pedoman Umum PNPM-Mandiri, 'Pedoman Umum Program Pemberdayaan Masyarakat Mandiri' (2007) <http://jdih.bpk.go.id/WpContent/Uploads/2012/02/Pedoman-PNPM-Mandiri_UMUM.Pdf> accessed 4 June 2021.

\section{Perundang-undangan}

Undang-Undang Nomor 17 Tahun 2007 tentang Rencana Pembangunan Jangka Panjang Nasional Tahun 2005 - 2025. 
Peraturan Presiden Nomor 7 Tahun 2005 tentang Rencana Pembangunan Jangka Menengah Nasional Tahun 2004-2009.

Peraturan Presiden Nomor 54 Tahun 2005 tentang Tim Koordinasi Penanggulangan Kemiskinan.

Keputusan Menteri Koordinator Kesejahteraan Rakyat selaku Ketua Tim Koordinasi Penanggulangan Kemiskinan No. 25/KEP/MENKO/KESRA/ VII/2007 tentang Pedoman Umum Program Pemberdayaan Masyarakat Mandiri (PNPM Mandiri).

How to cite: Aris Tri Wibowo, Abdul Madjid dan Rachmi Sulistyarini, 'Politik Hukum Pidana Pengelolaan Eks Dana Program Nasional Pemberdayaan Masyarakat Mandiri Perdesaan (PNPM-MPd)' (2021) Vol. 4 No. 3 Media Iuris. 
--Halaman ini sengaja dibiarkan kosong-- 